\title{
Afrikanerdom, Archives, and Change \\ The Archive for Contemporary Affairs at the University of the Free State, South Africa
}

\author{
KATE LAW AND HUIBRÉ LOMBARD*
}

\section{Introduction}

In South Africa in 1964 the National Party (NP) had been in power for sixteen years, Hendrik Verwoerd had been Prime Minister for six years, and the outcome of the Rivonia treason trial had sent the leadership of the African National Congress (ANC) to Robben Island where they faced sentences of life imprisonment. In the same year, at the then University of the Orange Free State, a campaign was launched to create and preserve political documents that related to South Africa's history since the end of the second South African War in 1902. In 1970, this initiative became a reality with the creation of the Institute of Contemporary History (INCH). ${ }^{1}$ As the material within this institute (now renamed the Archive for Contemporary Affairs [(ARCA]) testifies, the initiative to create an archive in the Free State celebrated a particular past that was designed to commemorate Afrikaner nationalism and the activities of the National Party. As such, this archive and the University of the Free State (UFS) that housed it had the reputation of being one of the last bastions of white Afrikanerdom in the new "Rainbow Nation." Considering the collections that the archive holds, this reputation is perhaps not undeserved. ${ }^{2}$ However, a closer look at this often neglected archive reveals its importance for scholars studying the rationales and discourses of apartheid and the history of the country more broadly.

This short article demonstrates that ARCA, like UFS, is undergoing a period of transformation in which it is broadening its collections to help create a more holistic picture of South Africa's past. This article briefly explores some of the most notable collections that ARCA holds and examines its recently acquired material. The article concludes by "assessing the health" of the archive more broadly by commenting on the ways in which the preservation of the past and nation building initiatives have intersected in the country since 1994.

\section{Archival Tensions}

In keeping with the history of UFS and the Free State province, ARCA's holdings are strong on white political history, particularly the history of the NP. Twenty years after the end of apartheid, although something of an arbitrary date, there seems to be 
enough temporal space for serious studies of white "high politics" that strike the balance between revisionism and emotive condemnation. As Hollander, Paul and Peters write: "Without a certain distance between one's present and the past under investigation, the contours of one's object of study remain vague and indiscernible." 3 A historian who has profitably used ARCA's holdings is Lindie Koorts in her biography of DF Malan, South Africa's Prime Minister between 1948 and 1954. For Koorts, "Twenty years after apartheid ended, a space has opened up for a new generation of historians to explore the past in its own right, and to challenge both Afrikaner and African nationalist stereotypes, without the constraints of yesteryear." 4 As Koorts' biography of Malan testifies, by reading the documents in institutions such as ARCA, scholars can access what imperial historians have long termed the "official mind." Unfortunately, as with archives the world over, and as Achille Mbembe argues, "archives are the product of a process which converts a certain number of documents into items judged to be worthy of preserving." 6 Thus, as Mbembe notes, the collation of material within any archive reflects tensions and biases of a particular past, with ARCA's collections being no different. In addition, as Lennart Bes has argued (in his report on the Dutch Records at the Tamil Nadu Archives), it is important to understand how, "highlighting certain parts of any archive might be considered a subjective affair." Nonetheless it is hoped that by (re)visiting documents of privileged elites, such as those connected to the NP housed in ARCA, scholars will be able to further interrogate the rise of Afrikaner nationalism, the impetus behind the move to apartheid and its subsequent implementation and dismantlement.

\section{Core Holdings}

The archive is responsible for the collection, safekeeping, arrangement and description of archivalia and for making it accessible to researchers. The archive collects correspondence, minutes, speeches, circulars, reports, memoranda, notes, diaries, pamphlets, photographs, and newspaper cuttings. It also has more than 2,000 sound recordings, which include parliamentary openings, speeches and special radio broadcasts. Apart from around 1,900 photographs of politicians, it also houses a number of other photographs in its private collections, as well as the photograph collection of Die Volksblad, a regional Afrikaans newspaper. Like many archives throughout the world, ARCA is placing greater emphasis on digitisation in an effort to expand and improve the visibility of its collections. Currently sixty-nine detailed inventories are available to consult online with one long-term goal being to steadily increase this number. A further 471 are available as scanned copies of old printed inventories listing the contents of specific collections.

ARCA's acquisition policy was historically driven by a desire to obtain private collections that relate to contemporary affairs, with the archive now housing over 940 private collections that are open to the public. ARCA's erstwhile department of newspaper cuttings (SA Media) provides access to a database with six million fulltext newspaper articles on twenty-three topics, collected daily from all mainline South African newspapers. As mentioned above, some of the most prominent holdings in ARCA's collection relate to the NP, particularly the papers of high-ranking officials. For instance, ARCA holds the papers of three state presidents: CR Swart, 
Nicolaas Diederichs, and Tom Naudé. ARCA's collections also contain the private papers of what Hermann Giliomee (whose papers are also housed at ARCA) has termed the "Last Afrikaner Leaders," namely the private papers of Hendrik Verwoerd, BJ Vorster, PW Botha, and FW de Klerk. ${ }^{8}$ The Verwoerd papers are vast: with the papers spanning the period 1932-66, the handlist alone is 134 pages. $^{9}$ Commonly perceived as the main architect of apartheid, the papers cover Verwoerd's period as editor of the nationalist newspaper Die Transvaler, his time as Minister of Native Affairs and his ascension to the position of Prime Minister following the death of JG Strijdom and ending with his assassination in 1966. Researchers interested in Verwoerd should also consult the ARCA papers of his private secretary JF Barnard, as well as those of his wife Betsie Verwoerd. The papers of BJ Vorster are similarly impressive in scope and are particularly rich for scholars interested in South Africa's foreign policy. ${ }^{10}$ Prime Minister for fourteen years (1966-78), Vorster's premiership witnessed the decolonisation of Angola and Mozambique, a development that changed the dynamics of regional politics, directly contributing to Rhodesian decolonisation in 1980. Perhaps the most interesting aspect of Vorster's papers is that they comprise largely of correspondence, thus they provide a different way to read the "official mind" of the NP. ARCA also has the papers of Vorster's wife, Tini, in its possession. By contrast, PW Botha's papers contain over 180 of his speeches, alongside constituency reports, personal correspondence and private diaries. ${ }^{11}$ More so than any of his predecessors, Botha fervently believed that the Soviet Union posed a greater threat to South Africa's stability than black political organisations. ${ }^{12}$ Botha's papers consequently provide crucial detail for scholars interested in the Cold War in Southern Africa. Like Verwoerd and Vorster, ARCA also possesses the papers of PW Botha's first wife, Elize. A study of Betsie Verwoerd, Tini Vorster, and Elize Botha's papers would bring a gendered dimension to the activities of the National Party and would challenge the notion that NP women were primarily Volksmoeders who consumed rather than helped to (re)produce broader nationalist culture.

The "Last Afrikaner Leader," FW de Klerk, also donated his papers to ARCA and is most well known for initiating a South African perestroika when he became president in 1989. FW de Klerk presided over arguably the most important period in South Africa's recent history with the release of Nelson Mandela and the transition to democracy in $1994 .{ }^{13}$ Continuing with the NP, ARCA's collection also contains the papers of NP branches, including the Free State, the Transvaal, Natal, and the Cape. All these papers are valuable for those working on the interplay between government policy in Pretoria and regional politics. In addition, ARCA is also home to the papers of several NP MPs, including André Bezuidenhout, Piet Clase, Francois Erasmus, Ernest Jansen, and Braam Raubenheimer. Thus researchers interested in how apartheid policy was interpreted and upheld in different locations should take collections such as these as their starting point. Scholarship that examined this regional aspect of apartheid would certainly nuance current historiographical debates and would be a valuable addition to understanding the evolution of nationalist ideology.

For researchers interested in the period of negotiation and transition between 1990 and 1994 as well as South Africa's subsequent reintegration into the world economy, ARCA has recently acquired the papers of RF "Pik" Botha, South Africa's 
longest serving Minister of Foreign Affairs. Botha's papers have wide resonance for scholars interested in diplomatic history, not only in the region but also more broadly as he was South Africa's permanent representative at the United Nations. These papers should also be consulted alongside the papers of Roelf Meyer, Hendrik Jacobus (Kobie) Coetsee, and Leon Wessels, three of the NP's key negotiators during the transition period. Scholars interested in the negotiation period should also consult the recently acquired Institute for Democracy in South Africa (IDASA) papers. Formed by Frederik Van Zyl Slabbert, IDASA was a liberal think tank that helped facilitate discussions between the NP and ANC during the transition period.

Alongside NP papers, ARCA has a significant number of collections that would also prove useful to scholars of Afrikaner nationalism, regional political economy, and the recent history of the entire sub-Saharan region. Of particular interest to those working on the cultural dimensions of nationalism would be the papers of the ATKV (Afrikaans Language and Culture Association), FAK (Federation of Afrikaans Cultural Association), Federale Vroueraad (Federal Women's League), and the South African Academy for Arts and Science. In addition, ARCA's collections also house information on a number of political parties, from across the political spectrum, including the ANC, Afrikaner Party, Labour Party, Democratic Party, Reunited National Party or People's Party, Inkatha Freedom Party, Conservative Party, National Party, National Conservative Party, National Union, New Order, New Republican Party, Progressive Federal Party, Progressive Party, South African Party, Unionist Party, United Party, and the Freedom Front. Broadening the scope of its political party holdings, ARCA launched a new initiative to collect archival material relating to women in politics as an attempt to address the andocentrism of its holdings. The first set of papers in this series are those of Sheila Camerer. A lawyer by background, Camerer was instrumental in drafting the Bill of Rights during the constitutional negotiations. Serving briefly as deputy justice minister in 1994, in 1997 she became the first ever woman and English speaker in NP history to hold the position of NP leader in the National Assembly. For more on the post-apartheid period, ARCA has also recently acquired the papers of Tony Leon, one time Democratic Party (DP) leader and fierce critic of Thabo Mbeki's government. After stepping down as the leader of the opposition party in 2007, Jacob Zuma appointed Leon as South Africa's ambassador to Argentina, Uruguay and Paraguay in 2009. Leon's papers are required reading for scholars interested in the nature of opposition politics and the trajectory of liberalism in the post-apartheid period.

Not least of interest to those working within the field of theology, another of ARCA's recent acquisitions are the papers of the church archive of the Free State Synod. Inter alia this collection contains statements and minutes of meetings that reflect upon the linkages between the church and the state. As Susan Rennie-Ritner argued nearly forty years ago, "religion has always been the most powerful formative influence in shaping the values, norms and institutions of the Afrikaner community." ${ }^{14}$ Scholars interested in mapping the connections between Afrikaner and Calvinist nationalisms and the subsequent construction of the white nation would therefore do well to take these papers as their starting point. Alongside works that foreground the political development of Afrikaner nationalism, ARCA is also home to various diverse collections that shed light on issues such as South Africa's economy and foreign policy, processes of industrialisation and agriculture, homeland 
administration, the military, the press and broadcasting, mining, unions, education, provincial affairs, sport, music, and social services. ${ }^{15}$

When read together with material in university archives in other parts of the country, ARCA's holdings on Afrikaner nationalism could help to reconfigure much historical writing. For instance, a study that read ARCA's NP material alongside the documents within the ANC's archives in Fort Hare, Alice, could usefully update works such as Edward Munger's Afrikaner and African Nationalism: South African Parallels and Parameters, now nearly forty years old. ${ }^{16}$

\section{ARCA's Place Within the Region}

Like other archives within the region, ARCA is redefining itself in the context of a democratic South Africa. In 1992, during the transition to democracy, the department of Arts and Culture established a commission on museums, monuments, and heraldry. Assessing the impact of a report produced by the aforementioned body, Verne Harris observed that, "the guiding principle must be the repositioning of the archive service within the structures necessary to liberate the minds and memory of ...people...so they can empower themselves as citizens of a democracy." ${ }^{17}$ This drive towards creating a more "comprehensive" archive recognised the role that archivists and institutions have in shaping social memory. Post-1994 South Africa saw a dramatic widening, and thus more holistic definition of the very essence of the "archive," as practitioners began to record the voices and experiences of the previously disenfranchised, usually through oral history, in an attempt to redress the historical biases of the official record. ${ }^{18}$ One practitioner involved in the lobby group the Archival Platform suggested that, "the argument we have been making is that the archive is absolutely central to nation building...first is that it often holds material that can tell us the past...the second way....is in regards to citizens holding their elected representatives to account." ${ }^{19}$ Despite the linkages the archive may have with post-apartheid nation building, rather depressingly, another regular archive user commented that some of the main users of archives are "relatively elderly white people" interested in genealogy and "for most South African[s] visiting an archive is as likely as going to the moon." ${ }^{20}$

The attempt to gather other voices to provide alternative views of history and the past has not, however, diluted the importance attached to institutions such as the National Archives (NA) in Pretoria. Despite being the country's flagship archive, in recent years the NA has been beset by a variety of systemic problems, including the sacking of senior personnel, a lack of funding, and a loss of expertise. ${ }^{21}$ According to one senior research professor at the University of Pretoria, the Department of Arts and Culture have singularly failed to prioritise archival funding, so much so that a career as an archivist is no longer seen as a viable career path. ${ }^{22}$ Yet, as Carolyn Hamilton has argued: "The current dilapidation of the South African national archival system is more a complex problem than simply a matter of inefficiency and bias." ${ }^{23}$ For Hamilton the fact that the NA is running into disrepair is largely as a "result of a lack of political vision and will." ${ }^{24}$ For Verne Harris, another reason for the neglect of the NA is "the widespread perception of the inherited colonial and apartheid state archives as racially obnoxious and irredeemably biased." ${ }^{25}$ In this context, the fact that government archives are going through a difficult period 
serves to further underscore the importance and adds significance to university and private archives such as ARCA.

As Robert Darnton's recent review of Arlette Farge's monograph The Allure of the Archives demonstrated, while history is both "tentative" and "concocted," even in the information age, archival research still forms the cornerstone of a large proportion of academic writing in the humanities. ${ }^{26}$ ARCA's great strength lies in its collections on South Africa's recent past, particularly the NP and evolution of nationalist ideology. While for some this elite history may not fit the vogue for histories of the cultural turn, as Hermann Giliomee argues, "the major duty of historians is to explain rather than apologise." 27 In terms of South Africa's racialised past, those seeking to do just that can find few better starting points than the material within ARCA's collections. 


\section{Bibliography of Works Cited}

Archive for Contemporary Affairs Home page, accessed 9 March 2014, http://supportservices. ufs.ac.za/content.aspx?DCode $=$ Z08.

Archive for Contemporary Affairs Useful Links page, accessed 17 March 2014, http://supportservices. ufs.ac.za/content.aspx?id=646.

Bes, L. "Hundreds of Rosetta Stones and Other Patient Papers: The Dutch Records at the Tamil Nadu Archives, Chennai (Madras)." Itinerario 37:1 (2003): 93-112.

Darnton, R. "The Good Way to Do History." The New York Review of Books 61.1 (9 January 2014), accessed 16 March 2014, http://www.nybooks.com/articles/archives/2014/jan/09/good-way-history/.

Email correspondence with academic and practitioner, University of Cape Town, February 2014.

Email correspondence with doctoral candidate, University of Pretoria, February 2014.

Email correspondence with senior academic, University of Pretoria, February 2014.

Gay and Lesbian Memory in Action, accessed 17 March 2014, http://www.gala.co.za/.

Giliomee, H. The Last Afrikaner Leaders: A Supreme Test of Power. Cape Town: Tafelberg, 2012.

Graham, M. "Finding Foreign Policy: Researching in Five South African Archives." History in Africa: A Journal of Method 37 (2010): 379-87.

Hamilton, C. "Forged and Continually Refashioned in the Crucible of Ongoing Social and Political Life: Archived and Custodial Practices as Subjects of Enquiry." South African Historical Journal 65:1 (2013): 1-22.

Handlist of PW Botha papers, accessed 10 March 2014, http://supportservices.ufs.ac.za/ dl/userfiles/Documents/00001/1173_eng.pdf.

Handlist of FW de Klerk papers, accessed 10 March 2014, http://supportservices.ufs.ac.za/ dl/userfiles/Documents/00001/1174_eng.pdf.

Handlist of Hendrik Verwoerd papers, accessed 10 March 2014, http://supportservices.ufs.ac.za/ dl/userfiles/Documents/00002/1887_eng.pdf.

Handlist of BJ Vorster papers, accessed 10 March 2014, http://supportservices.ufs.ac.za/ dl/Userfiles/Documents/00001/1197_eng.pdf.

Harris, V. "Redefining Archives in South Africa: Public Archives and Society in Transition, 1990-1996." Archivaria 42 (1996): 6-27.

Hollander, J. den, H. Paul, and R. Peters. "The Metaphor of Historical Distance." History and Theory 50:4 (2011): 1-10.

Jones, H. C. "Resources at the Institute for Contemporary History, University of the Orange Free State." History in Africa 20 (1993): 409.

Koorts, L. DF Malan and the Rise of Afrikaner Nationalism. Cape Town: Tafelberg, 2014.

Mbembe, Achille. "The Power of the Archive and its Limits." In Refiguring the Archive, edited by Carolyn Hamilton, 19-26. Cape Town: David Philip Publishers, 2002.

Munger, E. Afrikaner and African Nationalism: South African Parallels and Parameters. Oxford: Institute of Race Relations, Oxford University Press, 1967.

Phillips, M. "Distance and Historical Representation." History Workshop Journal 57 (2004): 123-41.

Rennie-Ritner, S. "The Dutch Reformed Church and Apartheid." Journal of Contemporary History 2:4 (1967): 17-37.

Robinson, R. and J. Gallagher. Africa and the Victorians: The Official Mind of Imperialism. London: Macmillan, 1961.

The Amazwi Abesifazane Cloth Project, accessed 17 March 2014, http://amazwi-voicesofwomen.com/.

"What's up at the Department of Arts and Culture," posted 4 November 2010, accessed 16 March 2014, http://www.archivalplatform.org/news/entry/whats_up/. 


\section{Notes}

* Kate Law is currently a post-doctoral fellow at the Centre for Africa Studies at UFS. She is a gender and empire historian who specialises in twentieth-century sub-Saharan African history. Huibré Lombard is the Head of the Archive for Contemporary Affairs at UFS. She holds a Master's degree in Information Science and a Master's degree in Translation Studies. Her interests focus on archives and digitisation as well as South African political history between 1948 and 1994.

1 Jones, "Resources at the Institute for Contemporary History," 409.

2 Archive for Contemporary Affairs Home page.

3 Hollander, et al. "The Metaphor of Historical Distance," 2. For more on "Historical Distance," see Phillips, "Distance and Historical Representation," 123-41.

4 Koorts, DF Malan, xii.

5 Robinson and Gallagher, Africa and the Victorians.

6 Mbembe, "The Power of the Archive and its Limits," 20.

7 Bes, "Hundreds of Rosetta Stones," 103.

8 Giliomee, The Last Afrikaner Leaders.

9 Handlist of Hendrik Verwoerd papers.

10 Handlist of BJ Vorster papers.
11 Handlist of PW Botha papers.

12 Giliomee, The Last Afrikaner Leaders, 145.

13 Handlist of FW de Klerk papers.

14 Rennie-Ritner, "The Dutch Reformed Church and Apartheid," 17.

15 Readers can use ARCA's website for further information on these issues.

16 Munger, Afrikaner and African Nationalism. For a discussion of other prominent archives within the country see Graham, "Finding Foreign Policy," 379-87.

17 Harris, "Redefining Archives in South Africa," 12.

18 See for instance: The Amazwi Abesifazane Cloth Project.

19 Email correspondence with academic and practitioner, University of Cape Town, February 2014.

20 Email correspondence with doctoral candidate, University of Pretoria, February 2014.

21 For more on this issue see "What's up at the Department of Arts and Culture."

22 Email correspondence with senior academic, University of Pretoria, February 2014.

23 Hamilton, "Forged and Continually Refashioned," 1.

24 Ibid., 3.

25 Harris, "Redefining Archives in South Africa," 20.

26 Darnton, "The Good Way to Do History."

27 Giliomee, The Last Afrikaner Leaders, 14. 